sobre-investimentos que demandam reorganização de libidinização; existe no repertório conceitual psicanalítico legitimado por este trabalho intenso que Maria Helena nos oferece.

Um trabalho de forte deslocamento de fronteiras, um trabalho de ampliação, realizado com cuidados no uso da mais delicada e possante ferramenta psicanalítica: a metapsicologia. A via permanece aberta.

Recebido em 28/4/ 2005

Aprovado em 29/ 5/ 2005

*Adaptado dos capítulos iniciais de 0 cavalei ro inexistente, de Italo Calvino

(São Paulo: Companhia das Letras, 1993).

Janete Frochtengarten

janfro@terra.com.br

\section{O CORPO EM PSICANÁLISE}

\section{Tatuagens e marcas corporais:} atualizações do sagrado. Ana Costa.

São Paulo: Casa do Psicólogo, 2003, 144p.

Analice de Lima Palombini

Professora do Instituto de Psicologia da UFRGS; mestre em Filosofia pela mesma Universidade; doutoranda do PPG em Saúde Coletiva, Instituto de Medicina Social da Uerj; psicóloga, psicanalista, membro daAssociação Psicanalítica de Porto Alegre.

Não é pequeno o desafio com o qual se confronta a psicanálise contemporânea: nascida a partir do advento da modernidade, como experiência relativa a uma interioridade conflituada, na busca de um sentido singular para a sua existência, vêse, hoje, às voltas com uma subjetividade exteriorizada, desprovida de introspecção e conflitos internos (BEZERRA JR, 2002). $\mathrm{Se}$, antes, as experiências subjetivas, purificadas conforme o método cartesiano, passavam a constituir o fundamento da verdade num mundo que, desgarrado de sua tradição, já não oferecia mais um terreno firme onde assentar as suas bases, agora, é a falência mesma do sujeito moderno, a falta de balizas interiores como critério de certeza que remetem ao corpo como reduto último e único de verdade.

Assim, a crença contemporânea no corpo - efeito de uma mudança na atmosfera sociocultural - manifesta de diversas formas a sua incidência sobre a psicanálise, seja no questionamento da validade de seu saber, confrontado à eficácia dos psicofármacos ou à praticidade das terapias corporais, seja pelo declínio do prestígio das psicanálises especialmente afeitas à linguagem, em favor daquelas que colocam a ênfase nos afetos e na sensorialidade.

Tatuagens e marcas corporais, sem desviarse das questões emergentes da contemporaneidade, responde de um outro lugar ao desafio a que a psicanálise é convocada, evitando a perspectiva dicotômica costumeira que encobre a insolubilidade do paradoxo que nos constitui. Diz Ana Costa:

"O que vem antes, o corpo ou a linguagem? Disjunção impossível que todos os sistemas humanostentaram produzir. Conciliar o inconciliável, subsumir o insubsumível, separar o inseparável: paradoxo incontornável que é característico do propriamente humano. Só para falar na neurose, a histeria, por exemplo, tenta fazer a junção, em uma relação de equivalência, desses dois heterogêneos; enquanto a obsessão tenta construí-los disjuntos. Assim, essa espécie de paradoxo, que é vivido como indeterminação, faz parte tanto da produção dos 
sintomas quanto "contamina" a própria produção em psicanálise." ( p.55)

Nesta direção, a autora reafirma sua filiação às formulações de Jacques Lacan, que, ao incluir ao Outro (corpo e significante) no circuito pulsional, rompe com o fechamento do sujeito numa mônada psíquica, sem com isso incorrer no equívoco de erigir em transcendência o Significante, tornado imune aos apelos da carne do mundo. Em seu livro anterior, Corpo e escrita (COSTA, 2001), Ana assim enuncia 0 irredutível da imbricação corpo/ linguagem:

"A experiência não pode ser reduzida ex-
clusivamente à referência a um símbolo
abstrato, ou auma imagem, ela precisa pas-
sar pelo corpo na sua relação com o seme-
Ihante e com o real (desde que este real
inclua alguma atividade, algum exercício).
É somente essa natureza mais extensa da
experiência que produz um registro que a
teoria lacaniana denominou de saber.
Como se pode depreender, o saber aqui se
diferenciada informação edo conhecimen-
to, namedida em queeleé necessariamen-
te corporal e, por isso, também incons-
ciente." (p.32-33)

Em Tatuagens e marcas corporais, a autora, fazendo-nos contornar o que seriam as bordas corporais, coloca-nos em contato com uma superfície discursiva que, qual uma fita de Moebius, ao mesmo tempo divide e torna um só natureza e cultura, experiência e representação, corpo e linguagem. Tatuagens e piercings, assim, são emblemas dessa composição em que a carne, sendo humana, traz em suas fibras já inscrita a cultura. Ou seja, se há uma natureza humana, ela se define por ser social: ser em relação ao seu meio, aos seus semelhantes, ao Outro.
Em dois capítulos que ocupam o centro do livro ("Sujeito da fantasia, objeto da pulsão" e "Interdição e diques"), Ana Costa apresenta os pressupostos psicanalíticos nos quais fundamenta sua leitura das diversas experiências contemporâneas relacionadas ao corpo: não apenas tatuagens e piercings ("Bordas corporais, bordas sociais"), mas também religião e ciência ("O esquecimento ocidental"), a liberação do exercício sexual ("A virgindade como tabu"), os regimes alimentares ("Ingestão e prazer"), a mística da mulher ("Stigmata, corpo místico e posição histérica" e "Poder e estigma") , entre outros temas que dão margem à retomada ao mesmo tempo inventiva e rigorosa de conceitos fundamentais em Freud e Lacan, reatualizando, com isso, a clínica psicanalítica de forma a fazer frente aos desafios que hoje se the apresentam.

É em torno das noções de fantasia e pulsão, interdição e gozo, que a autora tece essa espécie de rede conceitual na qual se sustentam as suas elaborações com respeito ao que emerge em corpo na contemporaneidade. Considerar a pulsão como expressão da incidência da linguagem no plano do corpo, conforme propõe Lacan, coloca em causa, aqui, o estatuto da relação entre corpo e cultura. Se uma primazia parece ser dada, então, à linguagem, como possibilidade de acesso mediado à experiência, é preciso considerar que essa linguagem é ligada ao ser no mundo, e apenas tem vigência em corpo, encarnada, incorporada. A linguagem é, ela mesma, uma experiência corporal, cuja operação desenha as bordas que definem, ao mesmo tempo e indissociavelmente, indivíduo e coletivo, natureza e cultura, corpo e Outro, numa junção que é também uma espé cie de mútua exclusão, um acoplamento nunca completado que se precipita 
como resto nas formações do inconsciente (chistes, sonhos, lapsos).

Sabemos que a ênfase que o século $X X$ vai atribuir ao corpo tem como uma de suas resultantes a produção de discursos múltiplos e fragmentados sobre o tema, tornando-se campo de uma batalha ideológica. Se distinções dicotômicas como substância/ experiência, sujeito/ objeto, mente/ corpo tornaram-se úteis metodologicamente, nem por isso constituem diferenças ontológicas, ainda que, no calor da batalha, sejam brandidas com ardor fundamentalista. A situação não é diferente no contexto da psicanálise. Nesse terreno, o trabalho corre o risco de se ver intei ramente lançado no campo simbólico, abstraído da concreção dos corpos, em função de uma relação idealizada com a palavra. Ana Costa lança alguma luz sobre as razões dessa abstração, que perpassa o percurso teórico de Lacan, assim como o de Freud: podemos compreendê-la aproximando as obras de ambos ao percurso próprio a uma análise e, portanto, ao percurso de todo analista.

Trata-se do caminho percorrido na relação ao Outro, que parte da ilusão de um significante desencarnado do corpo, da idealização do saber suposto ao analista, para, confrontado com a repetição, enfrentar o paradoxo da impossibilidade de substituir o registro corporal pelo registro da pal avra. Assim, os textos finais que, na obra de Freud como na de Lacan, apontam essa impossibilidade, operam como fim de análise que retroage sobre todo o percurso, permitindo ler, nos seus primórdios, aquilo que o seu término desvela.

Tatuagens e marcas corporais sustenta, do início ao fim, tal impossibilidade e nos revela uma autora que faz desdobrar a experiência de fim de análise em expe- riência de investigação clínica e produção teórica. 0 relevo que é dado, então, à linguagem, não implica em idealização da palavra. Ao contrário, pressupõe aceitação do paradoxo que, irredutível, seja ao corpo seja à linguagem, prescreve seus limites recíprocos. É dessa maneira que conceitos psicanalíticos fundamentais, formulados por Freud e por Lacan, investem-se da potência necessária para uma abordagem contemporânea do corpo na cultura.

Recebido em 13/ 9/2004

Aprovado em 11/ 10/ 2004

\section{REFERÊNCIAS}

BEZERRA JR., B. (2002) "O ocaso da interioridade e suas repercussões sobre a clínica", in PLASTINO, C.A. (org.). Transgressōes, Rio de Janeiro, Contra Capa.

COSTA, Ana. (2001) Corpo e escrita: relaçôes entre memória e transmissão da experiência. Rio de Janeiro: Relume-Dumará.

Analice de Lima Palombini analicepalombini@uol.com.br 